\title{
Helicobacter pylori infection and risk for developing dementia: an evidence-based meta-analysis of case-control and cohort studies
}

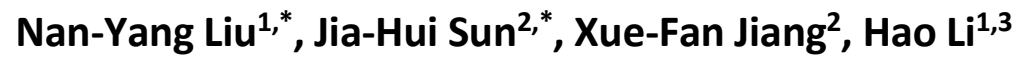 \\ ${ }^{1}$ Xiyuan Hospital, China Academy of Chinese Medical Sciences, Beijing, China \\ ${ }^{2}$ Beijing University of Traditional Chinese Medicine, Beijing, China \\ ${ }^{3}$ Wangjing Hospital, China Academy of Chinese Medical Sciences, Beijing, China \\ *Equal contribution
}

Correspondence to: Hao Li; email: 20190931822@bucm.edu.cn

Keywords: helicobacter pylori, dementia, Alzheimer's disease, systematic review and meta-analysis

Received: May 2, $2021 \quad$ Accepted: August 23, 2021

Published: September 24, 2021

Copyright: (C) 2021 Liu et al. This is an open access article distributed under the terms of the Creative Commons Attribution License (CC BY 3.0), which permits unrestricted use, distribution, and reproduction in any medium, provided the original author and source are credited.

\section{ABSTRACT}

Background: Infection with multiple pathogens may play a key role in the pathogenesis of dementia. Whether Helicobacter pylori $(H$. pylori) infection is associated causally with dementia is controversial.

Objective: We conduct a meta-analysis of case-control and cohort studies on the association between $\mathrm{H}$. pylori infection and the risk for all-cause and Alzheimer's disease (AD) dementia.

Methods: Two independent reviewers searched the PubMed, Cochrane Library, and Embase databases with English language restrictions from the date of conception to September 18, 2020. The primary analysis was as follows: the exposure variable was $H$. pylori infection, and the outcome was incident all-cause and AD dementia. Pooled odds ratios (OR), relative risk (RR), and corresponding $95 \%$ confidence intervals (CI) were obtained using the fixed-or random-effect model. Forest plots were generated to summarize the results.

Results: Ten studies involving 96,561 participants were included in the meta-analysis: 5 case-control studies and 5 cohort studies. The overall pooled cohort studies showed a significant positive association between $\mathrm{H}$. pylori infection and all-cause dementia with pooled RR of 1.36 (95\% $\mathrm{Cl}, 1.11-1.67)$. There was no association between H. pylori infection and risk for developing AD: RR of 1.33 (95\% Cl, 0.86-2.05) in cohort studies, and OR of 1.72 $(95 \% \mathrm{Cl}, 0.97-3.04)$ in case-control studies. Significant heterogeneity was showed in each comparison group.

Conclusion: This meta-analysis supports a positive association between $\boldsymbol{H}$. pylori infection and the risk of allcause dementia, but not AD dementia. Due to the interference of confounding factors, randomized controlled trials are needed to prove their causality.

\section{INTRODUCTION}

Dementia is a serious social and medical problem that affects the health of people older than 65 years worldwide. The most common types of dementia were Alzheimer's disease (AD) and vascular dementia, accounting for $60 \%-70 \%$ and $30 \%$, respectively. Currently, there are more than 50 million people with dementia worldwide, and this number will increase to 152 million by 2050 [1]. The 2019 Alzheimer's disease facts and figures in the United States showed that between 2000 and 2017, deaths resulting from stroke, heart disease, and prostate cancer decreased, whereas reported deaths from AD increased 145\% [1]. Such a situation is not optimistic in Asia. Recent data show that the number of dementia in China accounts for approximately $25 \%$ of the total number of dementia in the world [2].

The identified risk factors for dementia include sociodemographic structure (age, gender, low education level) and family history. In addition, infections, diabetes, hypertension, and stroke can also contribute to the occurrence of dementia [3]. Emerging data have 
demonstrated that infection with several important pathogens may be a hazard factor for cognitive impairment, dementia, and AD in particular [4]. Among them, Helicobacter pylori (H. pylori) is the most interesting for researchers $[5,6]$. H. pylori, the only microbial species currently known to survive in the human stomach, was successfully isolated from the gastric mucosa of patients with chronic active gastritis for the first time in 1984 [7]. Infection occurs mainly in childhood and generally survives in the body. However, most people are asymptomatic during infection [8]. Chronic H. pylori infection is a direct inducement of chronic gastritis, peptic ulcers, and gastric cancer. Interestingly, $H$. pylori has also been identified as a risk factor for non-gastrointestinal diseases, such as neurodegenerative diseases, including all-cause and $\mathrm{AD}$ dementia [9-11].

Previous evidence suggests $H$. pylori infection as a driver of cognitive decline. The potential link between $H$. pylori infection and dementia have been investigated by several population-based case-control and cohort studies, but the results were inconsistent. Although a previous meta-analysis that combined several observational studies have reported a statistically significant association between $H$. pylori infection and all-cause dementia, the evidence was limited to inappropriate statistical methods [12]. And one of the studies even included patients with mild cognitive impairment rather than the dementia, leading to unconvincing evidence. Therefore, the purpose of this study was to conduct a systematic review and metaanalysis of case-control and cohort studies to understand the association between $H$. pylori infection and the risk of developing all-cause and $\mathrm{AD}$ dementia.

\section{RESULTS}

\section{Literature search}

A total of 269 records were identified from all databases. After excluding 30 duplicate analysis, 239 records were filtered by reading the title and abstract. A total of 189 items were excluded due to irrelevant topics. We screened the full text of the remaining 50 studies and identified 10 studies that met the inclusion criteria of the meta-analysis, including 5 case-control studies and 5 cohort studies. The detailed PRISMA flowchart describing the literature search process is presented in Figure 1.

\section{Study characteristics and quality}

The ten studies, published between 2003 and 2018, varied in design, study population, sample size, outcome variables, and methods used to determine $\mathrm{H}$.

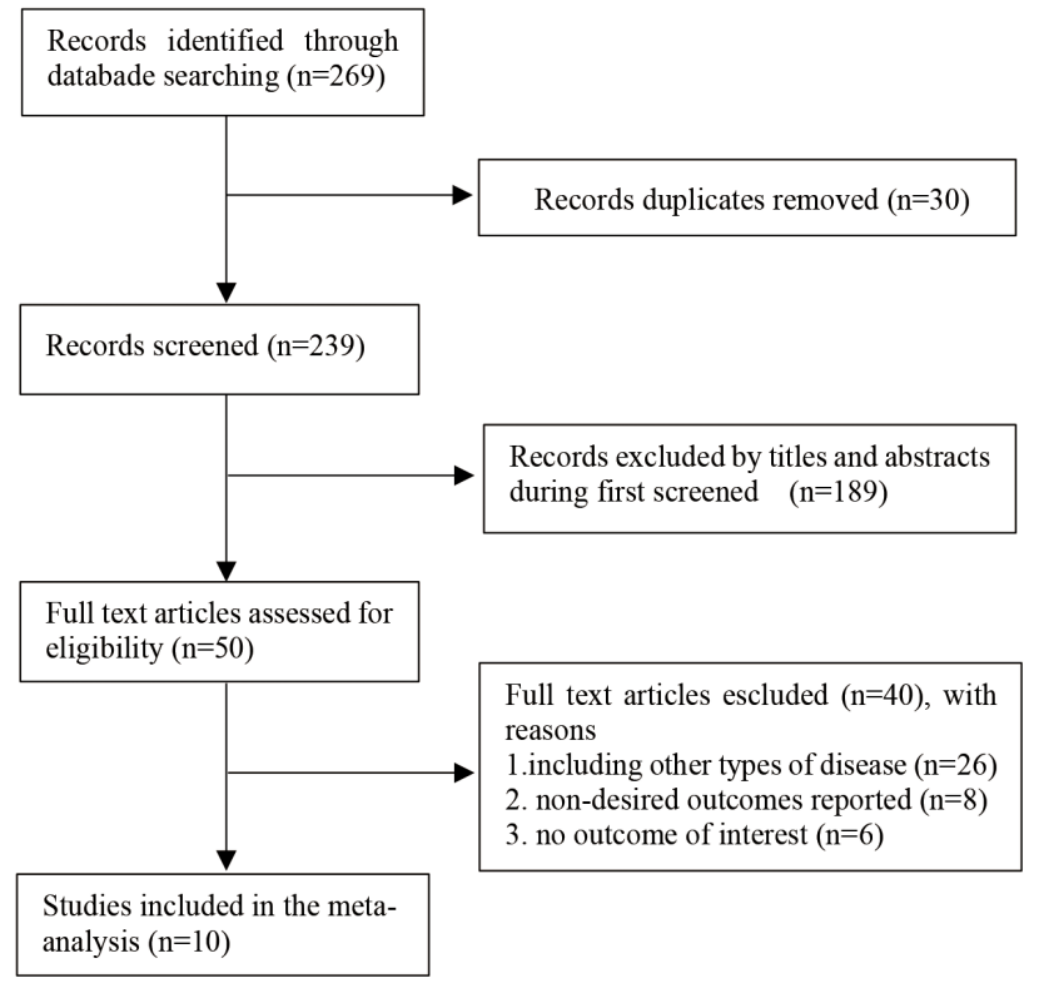

Figure 1. Flow diagram of the literature selection process. 
pylori infection. With respect to the countries that conducted these studies, one of them was conducted in the United States [13], six in Europe [14-19], two in China [20, 21], and one in Japan [22]. The sample sizes of the studies ranged from 61 to 83965 . Of five casecontrol studies, four studies used nondementia control groups [16, 19, 20, 22], and one study used an iron deficiency anemic control group [18]. Nine studies reported $\mathrm{AD}$ [13-16, 18-22], whereas 6 reported allcause dementia [13-17,21]. The follow-up time for the cohort study ranged from 3 to 20 years. The average age of the study samples in each group was between 59.3 and 78.5 years old. The identification of $H$. pylori infection involved serum $\operatorname{IgG}$ antibodies, rapid urine tests, and gastric mucosal histology. Six studies detected IgG antibodies in the serum [13-15, 17, 19, 20], and one study measured histology together with serum IgG antibodies [16]. One study was based on codes in the International Classification of Diseases 9th edition from national registries [21], one used histology [18] and one used rapid urine test [22]. Two of ten studies did not adjust for confounding factors [14, 16]. In the Newcastle-Ottawa scale assessment, all studies received a high score of $\geq 6$ stars, indicating that the quality of the literature was reliable (Table 1).

\section{Meta-analysis of the association between $H$. pylori infection and all-cause dementia in cohort study}

Five cohort studies investigated the correlation between $H$. pylori infection and all-cause dementia, including two retrospective and three prospective. Figure 2 shows the results of pooled RR with a random-effects model. Four studies demonstrated a significant positive association and the RR for the association ranged from 1.03 to 1.70 . Overall, the pooled results indicated that $H$. pylori infection participants had a considerably risk of developing all-cause dementia compared to those negative for $H$. pylori $(\mathrm{RR}=1.36 ; 95 \% \mathrm{CI}=1.11$ 1.67), with significant heterogeneity $\left(I^{2}=64.4 \%, P=\right.$ $0.024)$. Sensitivity analysis was assessed by removing each study in sequence and re-analysing the data shows that the study of Fani et al. has an impact on the results (Supplementary Figure 1). Interestingly, the heterogeneity decreased to $0 \%$ after excluding this study, while the effect estimates increased $(\mathrm{RR}=1.50$; 95\% CI $=1.31-1.73)($ Supplementary Figure 2$)$.

\section{Meta-analysis of the association between $\mathrm{H}$. pylori infection and AD dementia in cohort study}

Figure 3 shows the results of pooled RRs with a random-effect model of AD dementia. Four cohort studies reported the association between $H$. pylori infection and $\mathrm{AD}$ dementia, whereas two studies reported a significant positive association. The pooled
RRs of developing $\mathrm{AD}$ after $H$. pylori infection in cohort studies were $1.33 \quad(95 \%$ CI, 0.86-2.05), demonstrating that there is no causal association. Sensitivity analysis was used to assess the robustness of the results, which resulted in almost identical risk estimates. (Supplementary Figure 3).

\section{Meta-analysis of the association between $\boldsymbol{H}$. pylori infection and AD dementia in case-control study}

Five case-control studies described the connection between $H$. pylori infection and $\mathrm{AD}$ dementia. The pooled results of the random-effect model demonstrate that there is no correlation between $H$. pylori infection and the incidence of $\mathrm{AD}(\mathrm{OR}=1.72 ; 95 \% \mathrm{CI}=0.97-3.04)$ (Figure 4), with significant heterogeneity $\left(I^{2}=67.2 \%, P\right.$ $=0.016$ ). Evaluating the robustness of the results by removing each study in sequence and reanalyzing the data did not lead to remarkable difference in the results (Supplementary Figure 4). However, excluding the study of Kountouras et al. reduced the heterogeneity to $19.1 \%$ (Supplementary Figure 5).

\section{Publication bias}

The Begg rank correlation test and Egger linear regression test documented no evidence of publication bias among studies between $H$. pylori infection and the risk of all-cause and AD dementia (all $P<0.05$ ).

\section{DISCUSSION}

Previous researches have been performed to examine the association between $H$. pylori infection and various cognitive outcomes, including all-cause and $\mathrm{AD}$ dementia. However, the association is not fully understood [23-26]. Our results are limited to observational studies suggest that $H$. pylori infection may be an independent risk factor for all-cause dementia, but not for AD. In fact, the average follow-up time for these cohort studies is 3 to 20 years. This large time interval between the two diseases further confirms the assumption that $H$. pylori infection is an independent risk factor for all-cause dementia.

Positive correlation between $H$. pylori infection and allcause dementia was found in the previous metaanalysis, which is consistent with our findings. However, the authors pooled different study types results in significant heterogeneity, which reduced the credibility of the evidence. In addition, they included a study diagnosed as mild cognitive impairment rather than $\mathrm{AD}$ or all-cause dementia. Our evidence is based on independent cohort and case-control studies showing that $H$. pylori infection can lead to subsequent all-cause dementia, which makes the evidence more credible. 
Table 1. Characteristics of case-control and cohort studies included in the meta-analysis.

\begin{tabular}{|c|c|c|c|c|c|}
\hline Study & Year/location & Population/age M(SD) & Duration (yrs) & H. pylori detection & Outcome \\
\hline \multicolumn{6}{|l|}{ Cohort studies } \\
\hline Baudron [17] & 2013, France & $\begin{array}{c}\mathrm{N}=603 \\
\text { H. pylori positive } 73.1(6.4) \\
\text { H. pylori negative } 74.3(6.5)\end{array}$ & 20 & $\begin{array}{c}\text { Serum } H \text {. pylori } \operatorname{IgG} \\
\text { antibodies }\end{array}$ & all-cause dementia \\
\hline Huang [21] & 2014, Chian & $\begin{array}{l}\mathrm{N}=83965 \\
\text { H. pylori positive } 63.2(13.5) \\
\text { H. pylori negative } 63.6(13.4)\end{array}$ & 12 & $\begin{array}{l}\text { H. pylori infection } \\
\text { (ICD-9 code } 041.86 \text { ) }\end{array}$ & $\begin{array}{l}\text { all-cause } \\
\text { dementia; AD; } \\
\text { non-AD }\end{array}$ \\
\hline Fani [15] & $\begin{array}{l}\text { 2018, } \\
\text { Netherlands }\end{array}$ & $\begin{array}{c}\mathrm{N}=4275 \\
\text { H. pylori positive } 69.3(8.6) \\
\text { H. pylori negative } 67.5(8.5)\end{array}$ & 10.4 & $\begin{array}{c}\text { Serum } H . \text { pylori } \operatorname{IgG} \\
\text { antibodies }\end{array}$ & $\begin{array}{c}\text { all-cause } \\
\text { dementia; } \mathrm{AD}\end{array}$ \\
\hline Beydoun [13] & $\begin{array}{l}\text { 2018, United } \\
\text { States }\end{array}$ & $\begin{array}{l}\mathrm{N}=5927 \\
\text { H. pylori positive } 59.3(0.2) \\
\text { H. pylori negative } 62.8(0.4)\end{array}$ & 3 & $\begin{array}{c}\text { Serum } H . \text { pylori } \operatorname{IgG} \\
\text { antibodies }\end{array}$ & $\begin{array}{c}\text { all-cause } \\
\text { dementia; } \mathrm{AD}\end{array}$ \\
\hline Von [14] & 2018, France & $\mathrm{N}=689, \operatorname{Age} \geq 65$ & 10 & $\begin{array}{c}\text { Serum } H . \text { pylori } \operatorname{IgG} \\
\text { antibodies }\end{array}$ & $\begin{array}{c}\text { all-cause } \\
\text { dementia;AD }\end{array}$ \\
\hline \multicolumn{6}{|c|}{ Case control studies } \\
\hline Nagga [19] & 2003, Sweden & $\mathrm{N}=216, \operatorname{Age} \geq 60$ & NA & $\begin{array}{c}\text { Serum H. pylori } \mathrm{IgG} \\
\text { antibodies }\end{array}$ & $\mathrm{AD}, \mathrm{VaD}$ \\
\hline Kountouras [18] & 2006, Greece & $\begin{array}{c}\mathrm{N}=80 \\
\mathrm{AD} 65.0(6.9) \\
\text { Control 62.2(8.6) }\end{array}$ & NA & histologic analysis & $\mathrm{AD}$ \\
\hline Shiota [22] & 2011, Japan & $\begin{array}{c}\mathrm{N}=482 \\
\mathrm{AD} 74.4(10.4) \\
\text { Control } 78.5(6.4)\end{array}$ & NA & rapid urine test & $\mathrm{AD}$ \\
\hline $\mathrm{Bu}[20]$ & 2014, Chian & $\begin{array}{c}\mathrm{N}=263 \\
\mathrm{AD} 69(9) \\
\text { Control 70(10) }\end{array}$ & NA & $\begin{array}{c}\text { Serum } H . \text { pylori } \operatorname{IgG} \\
\text { antibodies }\end{array}$ & $\mathrm{AD}$ \\
\hline Tsolaki [16] & 2015, Greece & $\begin{array}{c}\mathrm{N}=61 \\
\mathrm{AD} 61.34(6.526) \\
\text { Control 62.41(4.49) } \\
\end{array}$ & NA & $\begin{array}{l}\text { Serum } H . \text { pylori } \operatorname{IgG} \\
\text { antibodies and } \\
\text { histological } \\
\end{array}$ & $\begin{array}{c}\text { all-cause } \\
\text { dementia; AD; } \\
\text { PD; LB; FTD }\end{array}$ \\
\hline
\end{tabular}

\begin{tabular}{lcc}
\hline Study & $\begin{array}{c}\text { Diagnostic } \\
\text { criteria }\end{array}$ & OR/HR, 95\% CI \\
\hline Baudron [17] & $\begin{array}{c}\text { NINCDS-AD- } \\
\text { RDA }\end{array}$ & Dementia: HR 1.46 (95\% CI 1.01-2.11) \\
& & Dementia: HR 1.51, 95\%CI 1.25-1.82 \\
Huang [21] & ICD-9-CM & AD: HR 0.66, 95\%CI 0.30-1.46 \\
& & Non-AD: HR 1.60, 95\%CI 1.32-1.95 \\
& & \\
Fani [15] & & \\
& DINCDS-AD- & Dementia: HR 1.03, 95\%CI 0.86-1.22 \\
& RDA & AD: HR 1.06 95\%CI 0.87-1.29
\end{tabular}
CVD

Age, sex, comorbidities hypertension, DM, depression, head injury

Adjusted for age, sex, study cohort, education, smoking, systolic and diastolic blood pressure, anti-hypertensive drug use, body mass index (BMI), cholesterol, high-density lipoprotein (HDL) cholesterol, triglycerides, APOE $\varepsilon$ carrier status, stroke, diabetes mellitus, ethnicity, and serum lipid-reducing agents. 


\begin{tabular}{|c|c|c|c|c|}
\hline Beydoun [13] & NA & $\begin{array}{l}\text { Dementia: HR1.44, 95\%CI 1.05-1.98 } \\
\text { AD: HR } 1.45 \text { (95\%CI 1.03-2.04) }\end{array}$ & $\begin{array}{l}\text { Adjusted for education, poverty income } \\
\text { ratio, smoking, weight ststus, } \\
\text { hypertension, diabetes, and dyslipidemia }\end{array}$ & 7 \\
\hline Von [14] & NA & $\begin{array}{l}\text { Dementia: HR } 1.70 \text { (95\% CI 1.05-2.74) } \\
\text { AD: HR } 2.85 \text { (95\% CI 1.58-5.12) }\end{array}$ & NA & 8 \\
\hline Nagga [19] & ICD-10 & $\begin{array}{l}\text { H. pylori positivity: } 55.3 \% \text { in } \mathrm{AD} \\
\text { patients, } 55.6 \% \text { in } \mathrm{AD} \text { with } \mathrm{CVD} \text {, } \\
49.2 \% \text { in } \mathrm{VaD}, 62.5 \% \text { in the cognitively } \\
\text { impaired group, } 50.5 \% \text { in the controls }\end{array}$ & Age & 6 \\
\hline Kountouras [18] & $\begin{array}{l}\text { NINCDS-AD- } \\
\text { AD-RDA }\end{array}$ & OR 8.4 (95\% CI 2.4-28.7) & $\begin{array}{l}\text { The groups were comparable regarding } \\
\text { SES }\end{array}$ & 7 \\
\hline Shiota [22] & $\begin{array}{l}\text { NINCDS-AD- } \\
\text { RDA }\end{array}$ & OR 0.94 (95\% CI 0.56-1.58) & Age, sex & 8 \\
\hline $\mathrm{Bu}[20]$ & $\begin{array}{l}\text { NINCDS-AD- } \\
\text { RDA }\end{array}$ & OR 1.39 (95\% CI 0.80-2.40) & $\begin{array}{c}\text { Age, sex, education, APOE, genotype, } \\
\text { CHD, DM, hypercholesterolemia, } \\
\text { hypertension }\end{array}$ & 6 \\
\hline Tsolaki [16] & $\begin{array}{l}\text { MMSE, } \\
\text { FRSSD, NI }\end{array}$ & $\begin{array}{l}68.33 \% \text { in patients with dementia } \\
45.16 \% \text { with control }\end{array}$ & NA & 6 \\
\hline
\end{tabular}

AD, Alzheimer's Disease; DSM-III-R, Statistical Manual of Mental Disorders-3rd Edition Revised; FRSSD, Functional Rating Scale for Symptoms of Delirium; ICD-9-CM, International Classification of Diseases 9, Ninth Revision, Clinical Modification; ICD-10, International Classification of Diseases 10; MMSE, Mini Mental State Examination; M(SD), Mean (standard deviation); N, Number of population; NA, not available; NINCDS-ADRDA, National Institute of Neurological Disorders and Stroke and Alzheimer's Disease and Related Disorders Association; NI, Neuropsychiatric Inventory.

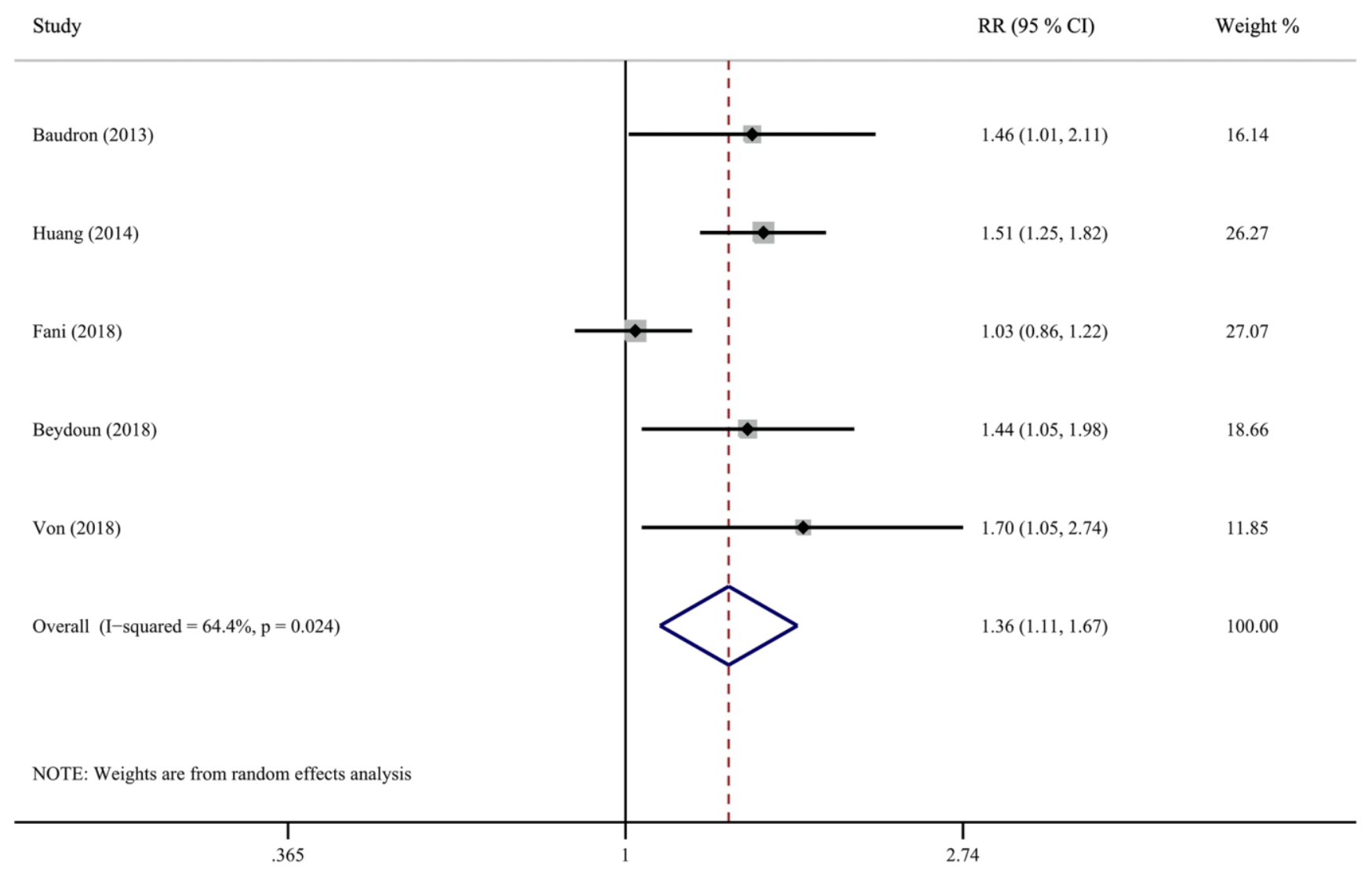

Figure 2. Forest plot presents the association between Helicobacter pylori infection and the risk of all-cause dementia in cohort study. 


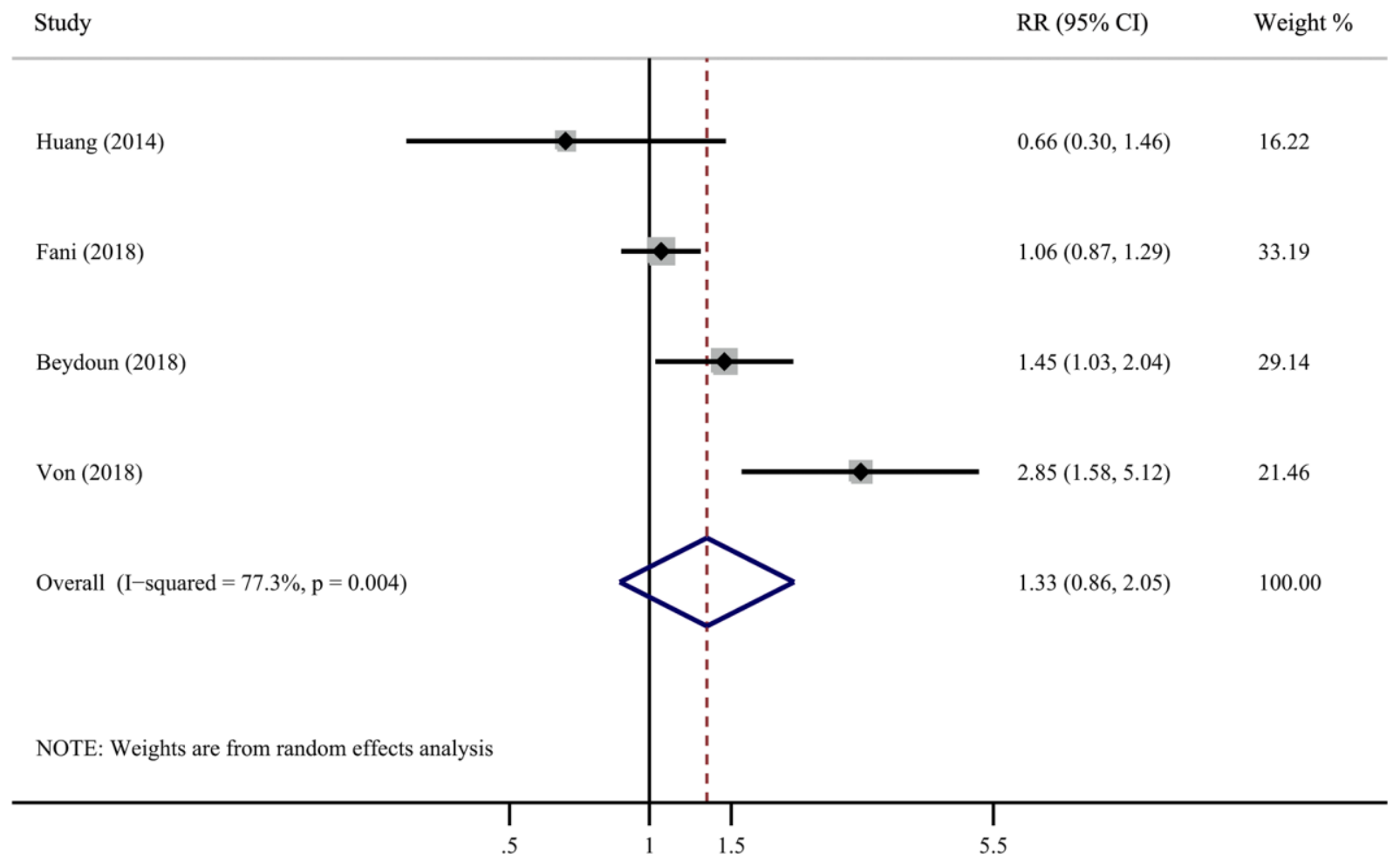

Figure 3. Forest plot presents the association between Helicobacter pylori infection and the risk of Alzheimer's disease in cohort study.

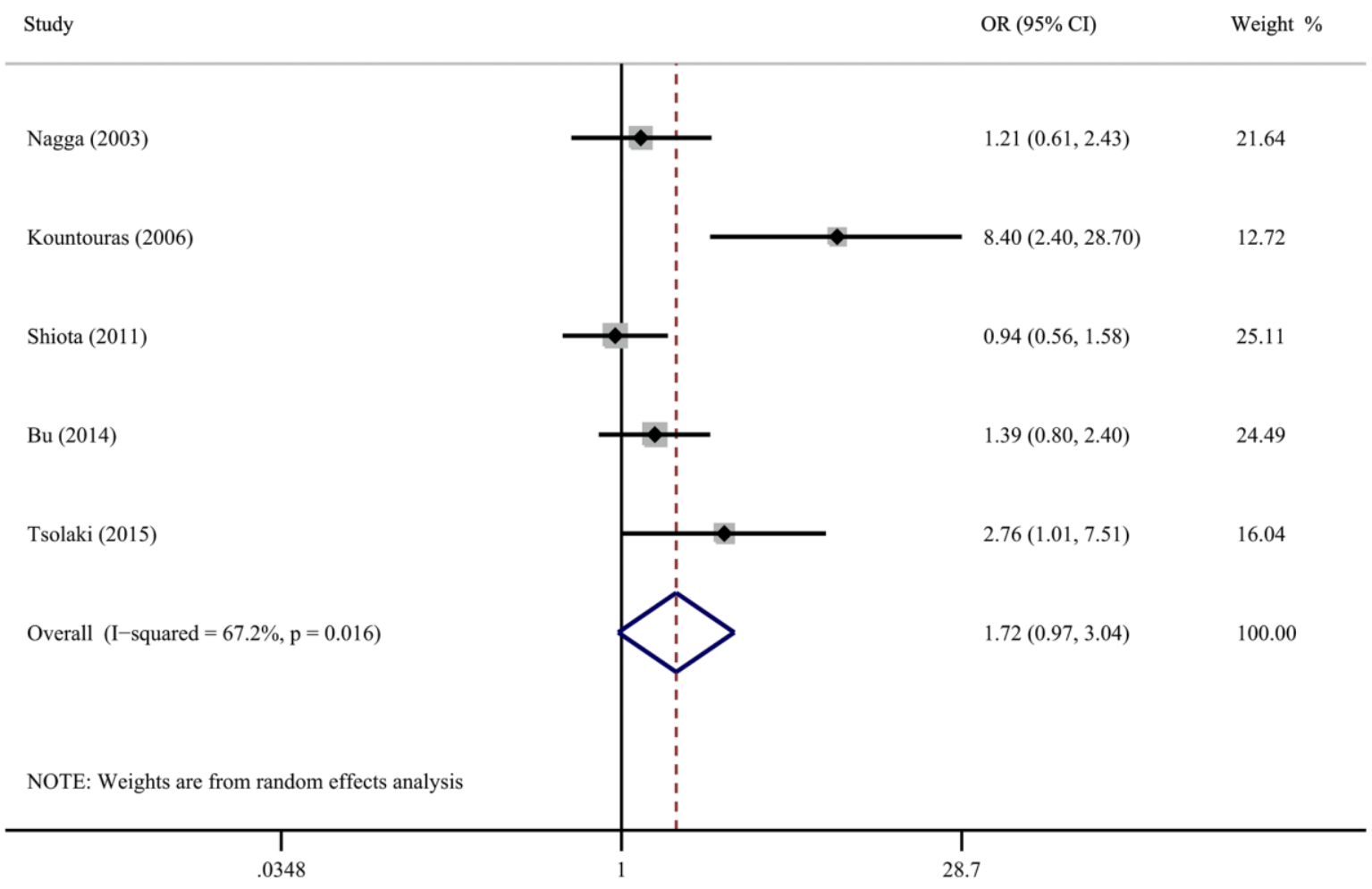

Figure 4. Forest plot presents the association between Helicobacter pylori infection and the risk of Alzheimer's disease in case-control study. 
Several neurological diseases related to $H$. pylori infection have been reported so far, such as $\mathrm{AD}$, stroke [27], Parkinson's disease [28] and multiple sclerosis [29]. In some disease, only the correlation is explained without a clear interpretation of the pathogenic mechanism, which makes this a very interesting and controversial topic. However, for some infected groups, the association is so powerful and the pathogenic mechanism is so obvious that guidelines for the treatment of $H$. pylori infection recommend that eradication treatment should be carried out in this case. Here, we focus on the connection among $H$. pylori infection and dementia. Multiple lines of evidence have suggested that infection with $H$. pylori is a key driver of $\mathrm{AD}$ [30-32]. One study reported beneficial effects on cognitive and functional status parameters of patients with $\mathrm{AD}$ after $H$. pylori eradication [33]. Another study showed a higher 5-year survival rate after $H$. pylori eradication in AD patients [34]. However, our study found no evidence supporting the connection between H. pylori infection and $\mathrm{AD}$ susceptibility, which is inconsistent with those reports. Inconsistent results may be limited by the ethnicity of the included population, study design, and $H$. pylori identification method.

The potential physiological mechanisms involved in $H$. pylori infection and dementia are uncertain, but several candidate mechanisms have been identified. One possible explanation is the neuroinflammation hypothesis that involves a central event triggering neurodegeneration, including AD [35, 36]. Previous researches have demonstrated that $H$. pylori infection may cause damage to the blood-brain barrier and induce neurological diseases by releasing various inflammatory mediators, for instance, cytokines and chemokines [37, 38]. H. pylori infection may also indirectly affect the brain by releasing multiple cytokines, for example, tumor necrosis factor- $\alpha$ and interleukin- 6 , maintaining cerebrospinal fluid inflammatory factors at a high level and thus inducing neuroinflammation [39, 40]. In another study, MNK-28 human gastric cells were incubated with $H$. pylori peptide, and activated genes were monitored [41]. The results showed that 77 genes were modulated by the $H$. pylori peptide, of which 65 are identified in the AlzBase database and contain the characteristics of AD. Additionally, a large proportion of modulated genes (30 out of 77) pertains to the inflammation pathway.

The other explanation is that chronic gastritis induced by $H$. pylori infection can cause vitamin $\mathrm{B} 12$ and folate malabsorption, which leads to the accumulation of folate 5-methyltetrahydrofolate and homocysteine [42-44]. Increased homocysteine can trigger endothelial atherosclerotic thrombotic disease and AD damage [45-47]. Multiple lines of evidence have confirmed this hypothesis. For example, hyperhomocysteinemia was demonstrated to be a strong independent factor in the progress of dementia [48]. Another study also revealed that homocysteine levels are associated with cardiovascular disease and dementia in the context of chronic gastritis (including H.pylori causality) [49]. The authors believe that vitamin B12, folate levels and suffering from atrophic gastritis are crucial determinants of homocysteine levels but are not associated with dementia. In addition, B12 deficiency resulting from by $H$. pylori infection may be related to activation of tau and $\beta$-amyloid (A $\beta$ ) deposition [50]. Recent evidence suggests that vitamin $B^{12}$ inhibits $A \beta_{42}$ aggregation in a concentration-dependent manner and protects amyloidinduced cytotoxicity of human neuronal cell lines [51]. An adequate supply of vitamin B12 appears to be essential to prevent cognitive decline and prevent the progression of $\mathrm{AD}[52]$.

It noticeable that observational studies cannot confirm causality. Despite that, our report meets the causality of some Hill criteria. First, there is a distinct time relationship in the cohort study. H. pylori infection preceded the occurrence of dementia in all preliminary studies. Given that $H$. pylori is acquired during childhood, the infection precedes the onset of dementia. Second, the positive associations between different studies and populations were extensively consistent. Third, as mentioned above, the hypothesis that $H$. pylori infection predisposes to dementia is biologically plausible.

\section{Sources of heterogeneity}

Significant heterogeneity was discovered in the current systematic review and meta-analysis due to clinical and methodological diversity, such as the differences in characteristics of demographic, determination of $H$. pylori infection and adjustment of confounding factors. The study of Fani et al. likely contributed to the heterogeneity in the exploration of the relationship between $H$. pylori infection and all-cause dementia [15]. In fact, the association in this study was significantly reduced compared with that in other studies, which may be due to the use of different diagnostic criteria. The pooled RR mildly increased after excluding this study (from 1.36 to 1.50), but there is no evidence of heterogeneity observed in the remaining researches $\left(I^{2}=0 \%, P=0.95\right)$. Additionally, the study of Kountouras et al. may be the main cause of heterogeneity due to a very strong association $(\mathrm{OR}=8.4)$. One possible reason accounting for this strong association may be that patients with anemia were included as the control group. Interestingly, previous evidence has suggested that patients with pernicious anemia were protected from infection with $H$. pylori [53]. 


\section{Limitation}

The potential limitations of current research warrant consideration. First, a direct causal relationship between $H$. pylori infection and $\mathrm{AD}$ or all-cause dementia risk cannot be determined because observational studies were included. Therefore, the results should be interpreted cautiously. Second, as a meta-analysis of observational researches published in English, publication bias may be possible. We conducted a comprehensive retrieval of the literature to eliminate publication bias as much as possible. Third, another possible restriction of the present systematic review and meta-analysis was the use of various detection methods for $H$. pylori infection. Fourth, substantial heterogeneity was found among studies. Although the main source of heterogeneity was detected through sensitivity analysis, we still cannot exclude the probability that residual confounding could influence the results. Finally, un-controlled or un-measurable risk factors in the study may produce biases. Although conventional risk factors have been adjusted in some studies, the possibility of residual confounding factors that increase the risk of dementia cannot be excluded.

\section{Suggestions for further study}

Based on our findings, several issues need to be considered. First, is there any causal relationship between $H$. pylori infection and $\mathrm{AD}$ dementia? To answer this question, the interval between the two diseases and adequate control of confounding factors should be assessed. Second, what is the exact mechanism by which $H$. pylori increase the risk of all-cause dementia? Neuroinflammation and hyperhomocysteinemia may provide some ideas. Third, can the eradication of $H$. pylori prevent or delay the development of dementia? Further studies are needed, including rigorously-designed clinical trials to tackle these issues to better understand this association and provide persuasive evidence for clinical practice in dementia prevention.

\section{CONCLUSIONS}

In conclusion, this systematic review and meta-analysis suggest that $H$. pylori infection may be associated with an increased risk of all-cause dementia, but not $\mathrm{AD}$ dementia. Future research on the pathogenic mechanism between the two diseases may lead to the development of novel therapies. The clinical implications lie in maintaining vigilance against dementia in elderly patients infected with $H$. pylori, and early detection and timely medical treatment for $H$. pylori patients through a multidisciplinary approach.

\section{MATERIALS AND METHODS}

\section{Search strategy and study selection}

This systematic review and meta-analysis were conducted based on the Meta-analysis Of Observational Studies in Epidemiology (MOOSE) [51]. Two independent reviewers (N-YL and J-HS) searched PubMed, the Cochrane Library, and Embase databases with English language restrictions from the inception to July 10, 2019. The search terms were "Helicobacter pylori/H. pylori or Campylobacter pylori/C. pylori" and at least one of the following: "dementia or Alzheimer's disease". Two independent researchers (N-YL and HL) evaluated the article abstracts determined by the initial search to ensure qualified study, and then obtained and evaluated all potentially relevant articles in detail. References from the latest reviews were also searched. Eligible studies were randomized controlled trials, controlled clinical trials, cohort studies, and casecontrol studies on the relationship between adult $H$. pylori infection and dementia. The study set the following criteria: (1) interest in exposure to $H$. pylori infection (yes or not); (2) interest in all-cause and AD dementia; (3) studies including relative risk (RR), hazard ratio (HR), or odds ratio (OR), and their corresponding $95 \%$ confidence intervals (CIs) and $P$ value (or calculated data). Intervention studies, case reports, case series, duplicate reports, letters to editors, comments, and author responses were excluded.

\section{Data extraction and quality assessment}

The standardized data form was used to extract the following information: author name, year of publication, country, period and follow-up time, reference materials, study design and population, sample size, $H$. pylori detection method, outcome variables, and statistical adjustment of confounding factors. The RR, HR, OR, and the corresponding CIs were extracted for each study (or calculated from reported data). We used the Newcastle-ottawa scale recommended by the Cochrane Collaboration to evaluate the methodological quality of the eligible studies [52]. The evaluation content includes three parts: selection, comparability, and exposure/outcome. There are 8 items in this scale with a total score of 9 . Quality assessments and data extraction were performed by two researchers (X-FJ and HL), and any discrepancies that existed were resolved by discussion.

\section{Statistical analysis}

Stata version 12.0 (Stata Corp LP, College Station, Texas) was used to calculate the pooled ORs, HRs, RRs, and 95\% CIs. Forest plots were generated to 
summarize the results. Heterogeneity $\chi^{2}$ test and $I^{2}$ index were used to assess the heterogeneity between the eligible studies. $I^{2} \leq 50 \%$ were deemed to have little heterogeneity; $I^{2}>50 \%$ were considered to have considerable heterogeneity. When heterogeneity cannot readily be interpreted, we incorporate it into a randomeffect model [53]. Instead, we used a fixed-effect model. Potential sources of heterogeneity were identified by sensitivity analysis. Publication bias was evaluated using the Begg rank correlation test or Egger linear regression test.

\section{Abbreviations}

$\mathrm{A} \beta$ : $\beta$-amyloid; AD: Alzheimer's disease; H. pylori: Helicobacter pylori; RR: relative risk; HR: hazard ratio; OR: odds ratio; CIs: 95\% confidence intervals.

\section{AUTHOR CONTRIBUTIONS}

Conceived and designed the experiments: HL. Performed the experiments: N-YL and J-HS. Analyzed the data: HL. Contributed reagents/materials/analysis tools: N-YL and X-FJ. Wrote the paper: N-YL. Read, reviewed and approved the final manuscript: N-YL, JHS, X-FJ, and HL. Had primary responsibility for final content: HL. All authors read and approved the final manuscript.

\section{ACKNOWLEDGMENTS}

We would like to thank all the authors who contributed to the systematic review.

\section{CONFLICTS OF INTEREST}

The authors declare that they have no conflicts of interest.

\section{FUNDING}

This work was supported by the China National Science and Technology Major Project for "Essential new drug research and development" (No.2018ZX09301038003). The funding source had no role in the study.

\section{REFERENCES}

1. Alzheimer's Association. Report:2019 Alzheimer's disease facts and figures. Alzheimers Dement. 2019; 15:321-87. https://doi.org/10.1016/i.jalz.2019.01.010

2. Jia L, Quan M, Fu Y, Zhao T, Li Y, Wei C, Tang Y, Qin Q, Wang F, Qiao Y, Shi S, Wang YJ, Du Y, et al, and Group for the Project of Dementia Situation in China.
Dementia in China: epidemiology, clinical management, and research advances. Lancet Neurol. 2020; 19:81-92. https://doi.org/10.1016/S1474-4422(19)30290-X PMID:31494009

3. Kalaria $R N$, Maestre $G E$, Arizaga $R$, Friedland $R P$, Galasko D, Hall K, Luchsinger JA, Ogunniyi A, Perry EK, Potocnik F, Prince M, Stewart R, Wimo A, et al, and World Federation of Neurology Dementia Research Group. Alzheimer's disease and vascular dementia in developing countries: prevalence, management, and risk factors. Lancet Neurol. 2008; 7:812-26.

https://doi.org/10.1016/S1474-4422(08)70169-8 PMID:18667359

4. Honjo K, van Reekum R, Verhoeff NP. Alzheimer's disease and infection: do infectious agents contribute to progression of Alzheimer's disease? Alzheimers Dement. 2009; 5:348-60.

https://doi.org/10.1016/i.jalz.2008.12.001 PMID:19560105

5. Linard M, Letenneur L, Garrigue I, Doize A, Dartigues JF, Helmer C. Interaction between APOE4 and herpes simplex virus type 1 in Alzheimer's disease. Alzheimers Dement. 2020; 16:200-08. https://doi.org/10.1002/alz.12008 PMID:31914220

6. Doulberis $M$, Kotronis $G$, Thomann $R$, Polyzos SA, Boziki M, Gialamprinou D, Deretzi G, Katsinelos $P$, Kountouras J. Review: Impact of Helicobacter pylori on Alzheimer's disease: What do we know so far? Helicobacter. 2018; 23:e12454. https://doi.org/10.1111/hel.12454 PMID:29181894

7. Ražuka-Ebela D, Giupponi B, Franceschi F. Helicobacter pylori and extragastric diseases. Helicobacter. 2018 (Suppl 1); 23:e12520. https://doi.org/10.1111/hel.12520 PMID:30203590

8. Roubaud-Baudron C, Blaszczyk L, Varon C, Chambonnier L, Giese A, Dubus P, Macrez N, Pietropaolo S, Leste-Lasserre T, Costet P, Rousseau B, Fenelon $\mathrm{V}$, Cho $\mathrm{Y}$, et al. Does helicobacter pylori infection impact the course of alzheimer's disease? an animal study. Helicobacter. 2014; 19:87.

9. Papaefthymiou $A$, Doulberis $M$, Katsinelos $P$, Liatsos $C$, Polyzos SA, Kotronis G, Papanikolaou K, Kountouras J. Impact of nitric oxide's bidirectional role on glaucoma: focus on Helicobacter pylori-related nitrosative stress. Ann N Y Acad Sci. 2020; 1465:10-28. https://doi.org/10.1111/nyas.14253 PMID:31642532

10. Kountouras J, Boziki M, Polyzos SA, Katsinelos $P$, Gavalas E, Zeglinas C, Tzivras D, Romiopoulos I, Giorgakis N, Anastasiadou K, Vardaka E, Kountouras C, Kazakos E, et al. The Emerging Role of Helicobacter Pylori-Induced Metabolic Gastrointestinal Dysmotility 
and Neurodegeneration. Curr Mol Med. 2017; 17:389-404.

https://doi.org/10.2174/1566524018666171219094837 PMID:29256351

11. Kountouras J, Boziki M, Polyzos SA, Katsinelos P, Gavalas E, Zeglinas C, Tzivras D, Romiopoulos I, Giorgakis N, Anastasiadou K, Vardaka E, Kountouras C, Kazakos $E$, et al. Impact of reactive oxygen species generation on Helicobacter pylori-related extragastric diseases: a hypothesis. Free Radic Res. 2017; 51:73-79. https://doi.org/10.1080/10715762.2016.1271122 PMID:28095729

12. Shindler-Itskovitch $T$, Ravona-Springer R, Leibovitz A, Muhsen K. A Systematic Review and Meta-Analysis of the Association between Helicobacterpylori Infection and Dementia. J Alzheimers Dis. 2016; 52:1431-42. https://doi.org/10.3233/JAD-160132 PMID:27079725

13. Beydoun MA, Beydoun HA, Elbejjani M, Dore GA, Zonderman AB. Helicobacter pylori seropositivity and its association with incident all-cause and Alzheimer's disease dementia in large national surveys. Alzheimers Dement. 2018; 14:1148-58.

https://doi.org/10.1016/i.jalz.2018.04.009 PMID: $\underline{30201100}$

14. Von Campe H, Peres K, Letenneur L, Linard M, Lehours P, Helmer C, Dartigues J, Roubaud BC. Helicobacter pylori infection is associated with an increased incidence of dementia in a cohort population study of old farmers. Helicobacter. 2018; 23:88-89.

15. Fani L, Wolters FJ, Ikram MK, Bruno MJ, Hofman A, Koudstaal PJ, Darwish Murad S, Ikram MA. Helicobacter pylori and the risk of dementia: $A$ population-based study. Alzheimers Dement. 2018; 14:1377-82.

https://doi.org/10.1016/j.jalz.2018.05.005

PMID:29935141

16. Tsolaki F, Kountouras J, Topouzis F, Tsolaki M. Helicobacter pylori infection, dementia and primary open-angle glaucoma: are they connected? BMC Ophthalmol. 2015; 15:24.

https://doi.org/10.1186/s12886-015-0006-2 PMID:25880776

17. Roubaud Baudron $C$, Letenneur L, Langlais $A$, Buissonnière A, Mégraud F, Dartigues JF, Salles N, and Personnes Agées QUID Study. Does Helicobacter pylori infection increase incidence of dementia? The Personnes Agées QUID Study. J Am Geriatr Soc. 2013; 61:74-78.

https://doi.org/10.1111/jgs.12065

PMID:23252507

18. Kountouras J, Tsolaki M, Gavalas E, Boziki M, Zavos C, Karatzoglou P, Chatzopoulos D, Venizelos I. P1-166:
Relationship between Helicobacter pylori infection and Alzheimer's disease. Alzheimers Dement. 2006; 2:S144. https://doi.org/10.1016/j.jalz.2006.05.542

19. Nägga $K$, Rajani $R$, Mårdh $E$, Borch $K$, Mårdh $S$, Marcusson J. Cobalamin, folate, methylmalonic acid, homocysteine, and gastritis markers in dementia. Dement Geriatr Cogn Disord. 2003; 16:269-75. https://doi.org/10.1159/000072812 PMID:14512723

20. Bu XL, Yao XQ, Jiao SS, Zeng $F$, Liu $Y H$, Xiang $Y$, Liang $\mathrm{CR}$, Wang QH, Wang X, Cao HY, Yi X, Deng B, Liu CH, et al. A study on the association between infectious burden and Alzheimer's disease. Eur J Neurol. 2015; 22:1519-25.

https://doi.org/10.1111/ene.12477 PMID:24910016

21. Huang WS, Yang TY, Shen WC, Lin CL, Lin MC, Kao CH. Association between Helicobacter pylori infection and dementia. J Clin Neurosci. 2014; 21:1355-58. https://doi.org/10.1016/j.jocn.2013.11.018 PMID:24629396

22. Shiota S, Murakami K, Yoshiiwa A, Yamamoto K, Ohno S, Kuroda A, Mizukami K, Hanada K, Okimoto T, Kodama M, Abe K, Yamaoka Y, Fujioka T. The relationship between Helicobacter pylori infection and Alzheimer's disease in Japan. J Neurol. 2011; 258:1460-63.

https://doi.org/10.1007/s00415-011-5957-5 PMID:21336779

23. Han ML, Chen JH, Tsai MK, Liou JM, Chiou JM, Chiu MJ, Chen YC. Association between Helicobacter pylori infection and cognitive impairment in the elderly. J Formos Med Assoc. 2018; 117:994-1002. https://doi.org/10.1016/j.jfma.2017.11.005 PMID:29175144

24. Rezvani F, Sayadnasiri M, Rezaei O. The study of memory and executive dysfunction in patients infected with Helicobacter pylori. Neurol Res. 2017; 39:953-58. https://doi.org/10.1080/01616412.2017.1363349 PMID:28791919

25. Xu Y, Wang Q, Liu Y, Cui R, Lu K, Zhao Y. Association between Helicobacter pylori infection and carotid atherosclerosis in patients with vascular dementia. J Neurol Sci. 2016; 362:73-77.

https://doi.org/10.1016/j.jns.2016.01.025

PMID:26944122

26. Xu Y, Wang $Q$, Liu Y, Cui R, Zhao Y. Is Helicobacter pylori infection a critical risk factor for vascular dementia? Int J Neurosci. 2016; 126:899-903. https://doi.org/10.3109/00207454.2015.1081387 PMID:26269142

27. Alvarez-Arellano L, Maldonado-Bernal C. Helicobacter pylori and neurological diseases: Married by the laws 
of inflammation. World J Gastrointest Pathophysiol.

2014; 5:400-04.

https://doi.org/10.4291/wjgp.v5.i4.400

PMID:25400983

28. Shen X, Yang H, Wu Y, Zhang D, Jiang H. Meta-analysis: Association of Helicobacter pylori infection with Parkinson's diseases. Helicobacter. 2017; 22:e12398. https://doi.org/10.1111/hel.12398 PMID:28598012

29. Cook KW, Crooks J, Hussain K, O’Brien K, Braitch M, Kareem H, Constantinescu CS, Robinson K, Gran B. Helicobacter pylori infection reduces disease severity in an experimental model of multiple sclerosis. Front Microbiol. 2015; 6:52.

https://doi.org/10.3389/fmicb.2015.00052

PMID:25762984

30. Doulberis $M$, Kotronis $G$, Gialamprinou D, Polyzos SA, Papaefthymiou A, Katsinelos P, Kountouras J. Alzheimer's disease and gastrointestinal microbiota; impact of Helicobacter pylori infection involvement. Int J Neurosci. 2021; 131:289-301.

https://doi.org/10.1080/00207454.2020.1738432 PMID:32125206

31. Santos ML, de Brito BB, da Silva FA, Sampaio MM, Marques HS, Oliveira E Silva N, de Magalhães Queiroz DM, de Melo FF. Helicobacter pylori infection: Beyond gastric manifestations. World J Gastroenterol. 2020; 26:4076-93.

https://doi.org/10.3748/wjg.v26.i28.4076 PMID:32821071

32. Albaret $G$, Sifré $E$, Floch $P$, Laye $S$, Aubert A, Dubus $P$, Azzi-Martin L, Giese A, Salles N, Mégraud F, Varon C, Lehours P, Roubaud-Baudron C. Alzheimer's Disease and Helicobacter pylori Infection: Inflammation from Stomach to Brain? J Alzheimers Dis. 2020; 73:801-09.

https://doi.org/10.3233/JAD-190496

PMID:31868664

33. Kountouras J, Boziki M, Gavalas E, Zavos C, Grigoriadis N, Deretzi G, Tzilves D, Katsinelos P, Tsolaki M, Chatzopoulos D, Venizelos I. Eradication of Helicobacter pylori may be beneficial in the management of Alzheimer's disease. J Neurol. 2009; 256:758-67.

https://doi.org/10.1007/s00415-009-5011-z

PMID:19240960

34. Kountouras J, Boziki M, Gavalas E, Zavos C, Deretzi G, Chatzigeorgiou S, Katsinelos P, Grigoriadis N, GiartzaTaxidou E, Venizelos I. Five-year survival after Helicobacter pylori eradication in Alzheimer disease patients. Cogn Behav Neurol. 2010; 23:199-204. https://doi.org/10.1097/WNN.0b013e3181df3034 PMID:20829670
35. Ardura-Fabregat A, Boddeke EW, Boza-Serrano A, Brioschi S, Castro-Gomez S, Ceyzériat K, Dansokho C, Dierkes T, Gelders G, Heneka MT, Hoeijmakers L, Hoffmann A, laccarino $L$, et al. Targeting Neuroinflammation to Treat Alzheimer's Disease. CNS Drugs. 2017; 31:1057-82.

https://doi.org/10.1007/s40263-017-0483-3

PMID:29260466

36. Sung PS, Lin PY, Liu CH, Su HC, Tsai KJ. Neuroinflammation and Neurogenesis in Alzheimer's Disease and Potential Therapeutic Approaches. Int J Mol Sci. 2020; 21:701.

https://doi.org/10.3390/ijms21030701

PMID:31973106

37. Kountouras J, Deretzi G, Gavalas E, Zavos C, Polyzos SA, Kazakos E, Giartza-Taxidou E, Vardaka E, Kountouras C, Katsinelos P, Boziki M, Giouleme O. A proposed role of human defensins in Helicobacter pylori-related neurodegenerative disorders. Med Hypotheses. 2014; 82:368-73.

https://doi.org/10.1016/i.mehy.2013.12.025 PMID:24472867

38. Deretzi G, Kountouras J, Polyzos SA, Zavos C, GiartzaTaxidou E, Gavalas E, Tsiptsios I. Gastrointestinal immune system and brain dialogue implicated in neuroinflammatory and neurodegenerative diseases. Curr Mol Med. 2011; 11:696-707. https://doi.org/10.2174/156652411797536660 PMID:21902649

39. Yun $\mathrm{CH}$, Lee HY, Lee SK, Kim H, Seo HS, Bang SA, Kim SE, Greve DN, Au R, Shin C, Thomas RJ. Amyloid Burden in Obstructive Sleep Apnea. J Alzheimers Dis. 2017; 59:21-29.

https://doi.org/10.3233/JAD-161047

PMID:28550245

40. Sugimoto M, Yamaoka Y. Virulence factor genotypes of Helicobacter pylori affect cure rates of eradication therapy. Arch Immunol Ther Exp (Warsz). 2009; 57:45-56.

https://doi.org/10.1007/s00005-009-0007-z PMID:19219527

41. Contaldi F, Capuano F, Fulgione A, Aiese Cigliano R, Sanseverino W, lannelli D, Medaglia C, Capparelli R. The hypothesis that Helicobacter pylori predisposes to Alzheimer's disease is biologically plausible. Sci Rep. 2017; 7:7817.

https://doi.org/10.1038/s41598-017-07532-x PMID:28798312

42. Hinterberger M, Fischer P. Folate and Alzheimer: when time matters. J Neural Transm (Vienna). 2013; 120:211-24.

https://doi.org/10.1007/s00702-012-0822-y

PMID:22627695 
43. Muhsen K, Cohen D. Helicobacter pylori infection and iron stores: a systematic review and meta-analysis. Helicobacter. 2008; 13:323-40.

https://doi.org/10.1111/i.1523-5378.2008.00617.x PMID:19250507

44. Chung SD, Sheu JJ, Kao LT, Lin HC, Kang JH. Dementia is associated with iron-deficiency anemia in females: a population-based study. J Neurol Sci. 2014; 346:90-93. https://doi.org/10.1016/i.jns.2014.07.062 PMID:25127441

45. Kountouras J, Gavalas E, Zavos C, Stergiopoulos C, Chatzopoulos D, Kapetanakis N, Gisakis D. Alzheimer's disease and Helicobacter pylori infection: Defective immune regulation and apoptosis as proposed common links. Med Hypotheses. 2007; 68:378-88.

https://doi.org/10.1016/j.mehy.2006.06.052 PMID:16979298

46. Sipponen $\mathrm{P}$, Laxén $\mathrm{F}$, Huotari $\mathrm{K}$, Härkönen $\mathrm{M}$. Prevalence of low vitamin B12 and high homocysteine in serum in an elderly male population: association with atrophic gastritis and Helicobacter pylori infection. Scand J Gastroenterol. 2003; 38:1209-16. https://doi.org/10.1080/00365520310007224 PMID:14750639

47. Smith $A D$, Refsum $H$, Bottiglieri $T$, Fenech $M$, Hooshmand B, McCaddon A, Miller JW, Rosenberg IH, Obeid R. Homocysteine and Dementia: An International Consensus Statement. J Alzheimers Dis. 2018; 62:561-70. https://doi.org/10.3233/JAD-171042 PMID:29480200

48. Adriani A, Fagoonee S, De Angelis C, Altruda F, Pellicano R. Helicobacter pylori infection and dementia: can actual data reinforce the hypothesis of a causal association? Panminerva Med. 2014; 56:195-99.

PMID:25056243
49. Redéen S, Ryberg A, Petersson F, Eriksson O, Nägga K, Borch K. Homocysteine levels in chronic gastritis and other conditions: relations to incident cardiovascular disease and dementia. Dig Dis Sci. 2010; 55:351-58.

https://doi.org/10.1007/s10620-009-0761-0

PMID:19267198

50. Román GC, Mancera-Páez O, Bernal C. Epigenetic Factors in Late-Onset Alzheimer's Disease: MTHFR and CTH Gene Polymorphisms, Metabolic Transsulfuration and Methylation Pathways, and B Vitamins. Int J Mol Sci. 2019; 20:319.

https://doi.org/10.3390/ijms20020319

PMID:30646578

51. Alam P, Siddiqi MK, Chaturvedi SK, Zaman M, Khan RH. Vitamin B12 offers neuronal cell protection by inhibiting $A \beta-42$ amyloid fibrillation. Int $J$ Biol Macromol. 2017; 99:477-82.

https://doi.org/10.1016/j.ijbiomac.2017.03.001 PMID:28267610

52. Román GC, Jackson RE, Gadhia R, Román AN, Reis J. Mediterranean diet: The role of long-chain $\omega-3$ fatty acids in fish; polyphenols in fruits, vegetables, cereals, coffee, tea, cacao and wine; probiotics and vitamins in prevention of stroke, age-related cognitive decline, and Alzheimer disease. Rev Neurol (Paris). 2019; 175:724-41.

https://doi.org/10.1016/i.neurol.2019.08.005 PMID:31521398

53. Fong $T L$, Dooley $C P$, Dehesa $M$, Cohen $H$, Carmel $R$, Fitzgibbons PL, Perez-Perez GI, Blaser MJ. Helicobacter pylori infection in pernicious anemia: a prospective controlled study. Gastroenterology. 1991; 100:328-32. https://doi.org/10.1016/0016-5085(91)90199-u PMID:1985031 


\section{SUPPLEMENTARY MATERIALS}

\section{Supplementary Figures}

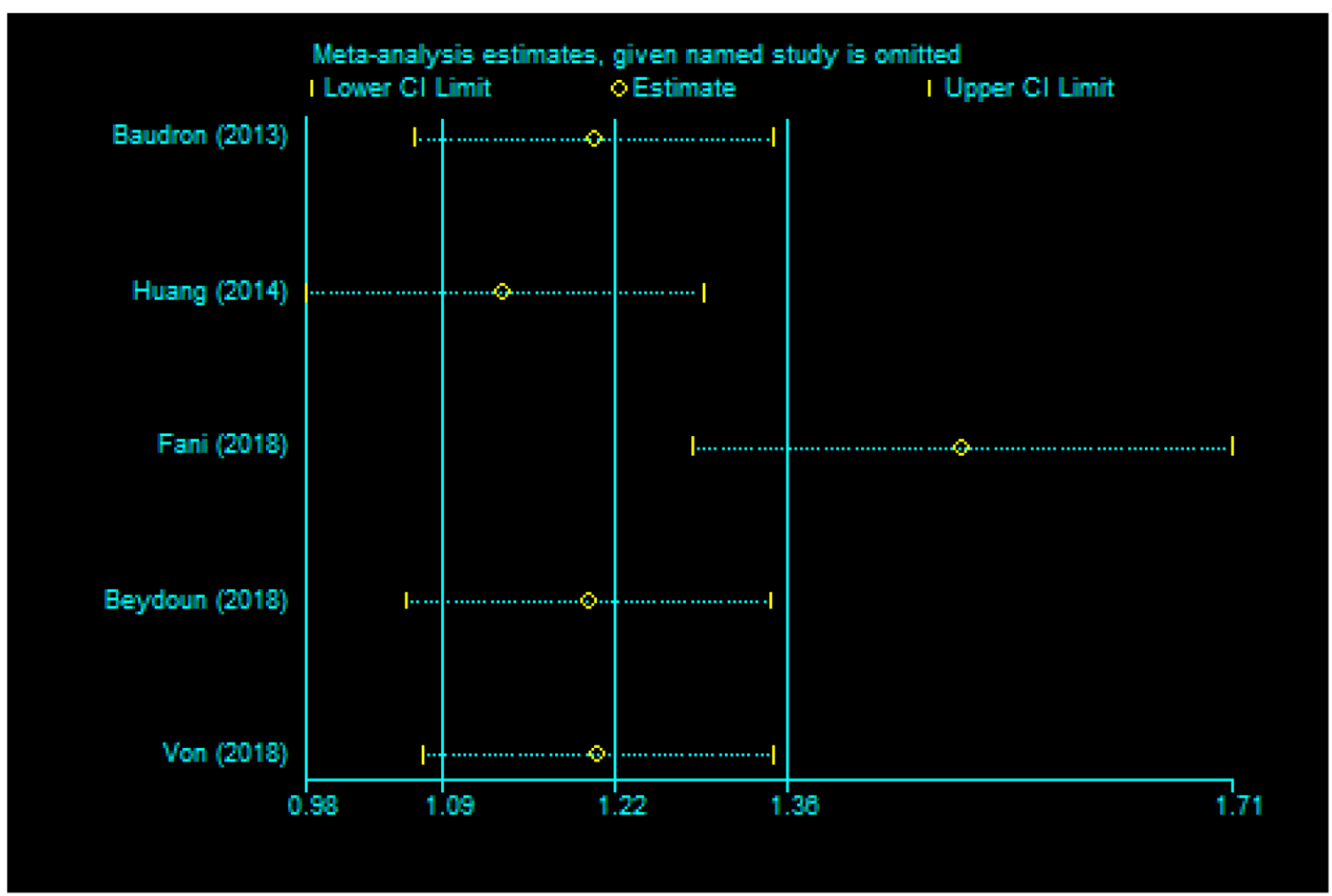

Supplementary Figure 1. Sensitivity analysis of the association between Helicobacter pylori infection and all-cause dementia in cohort study. 


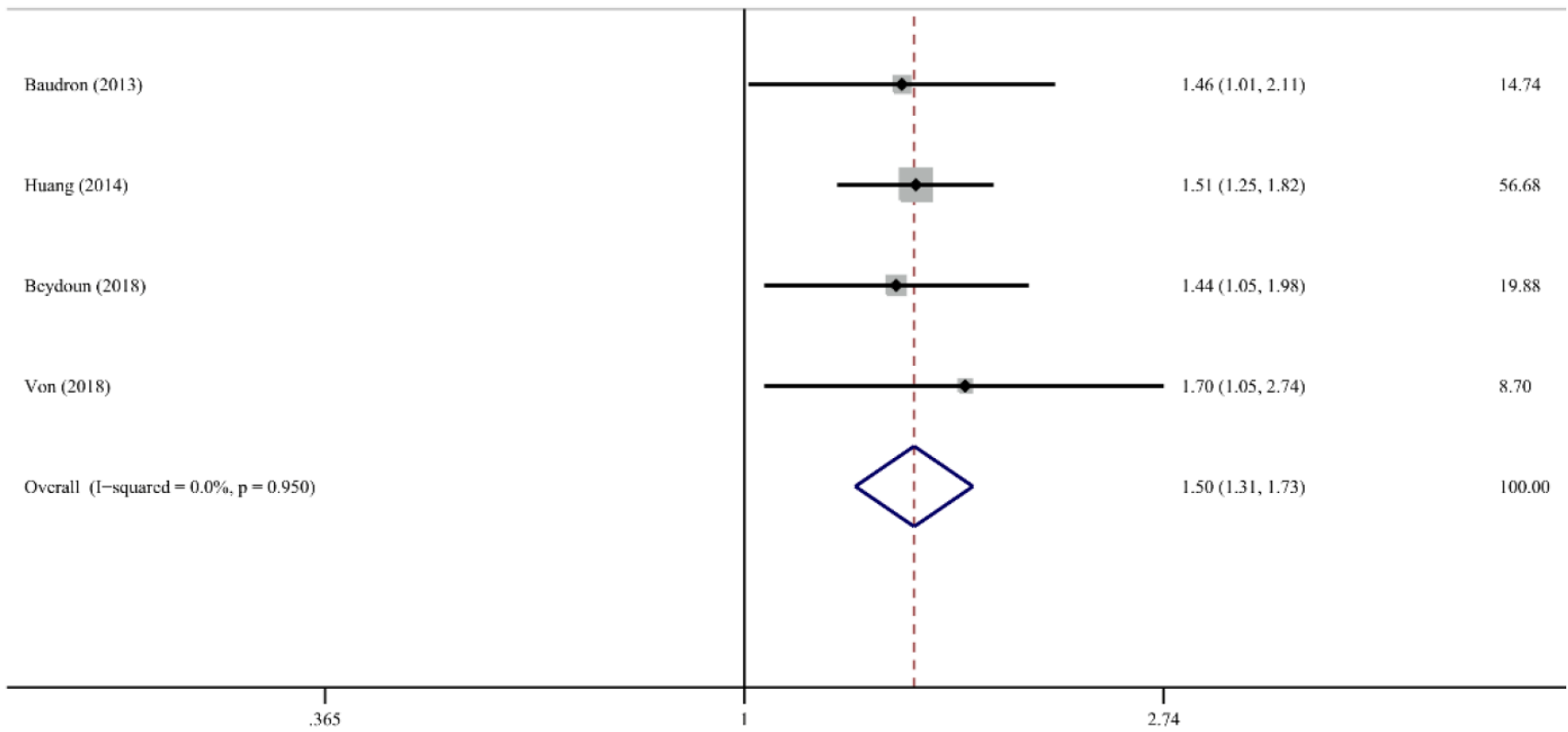

Supplementary Figure 2. Re-analysing the association between Helicobacter pylori infection and all-cause dementia after excluding the study of Fani et al. 


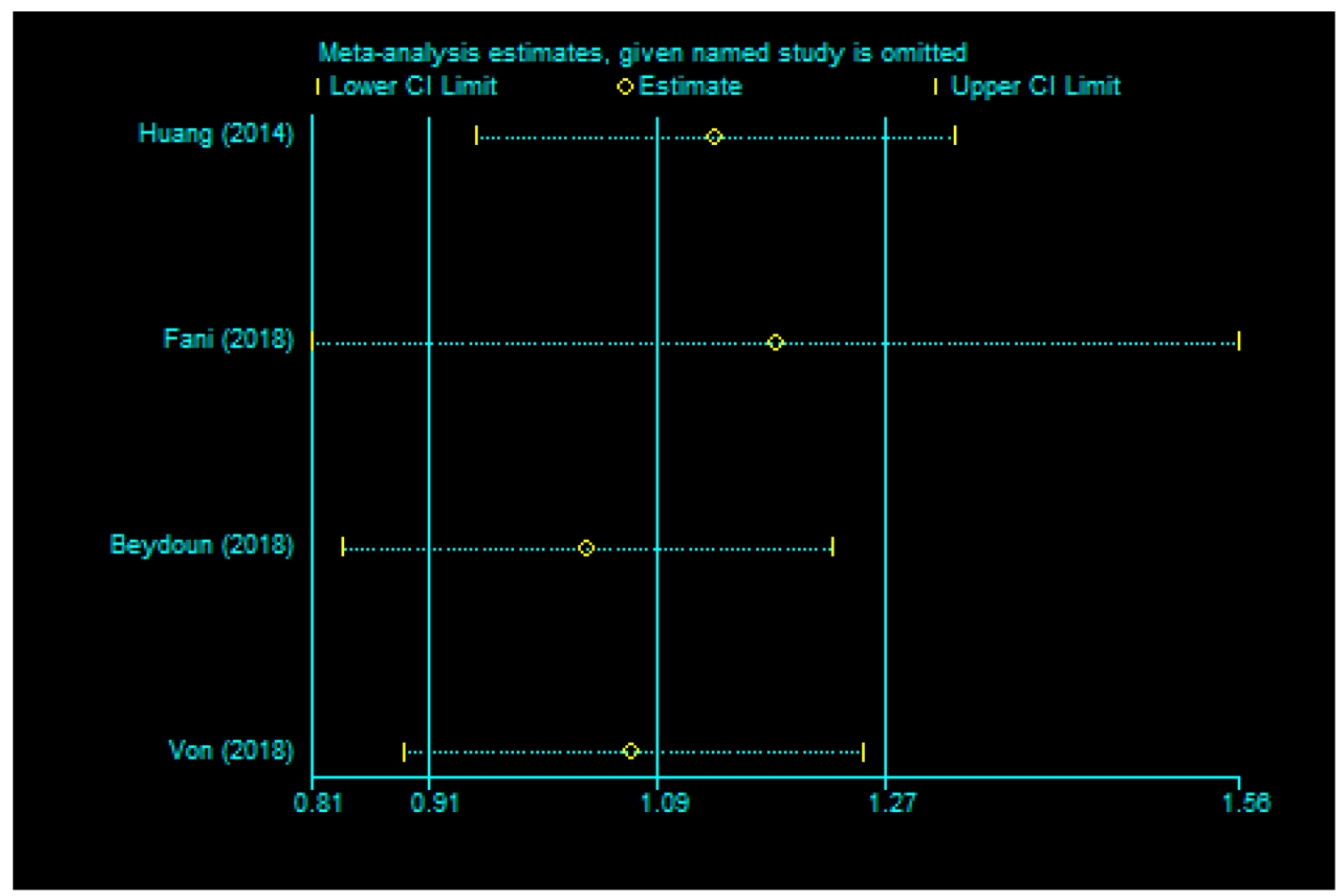

Supplementary Figure 3. Sensitivity analysis of the association between Helicobacter pylori infection and AD in cohort study. 


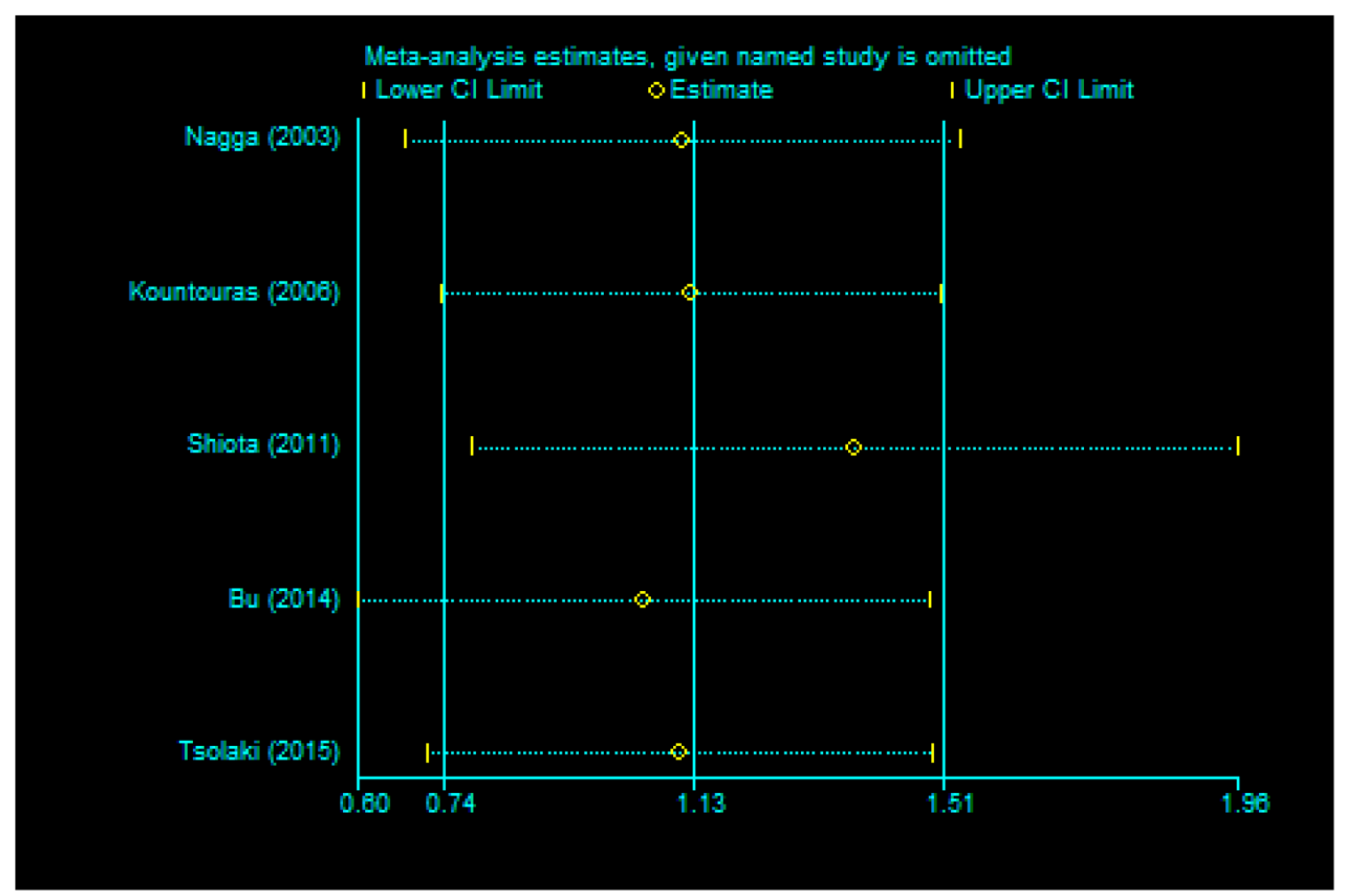

Supplementary Figure 4. Sensitivity analysis of the association between Helicobacter pylori infection and AD in case-control study. 


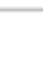

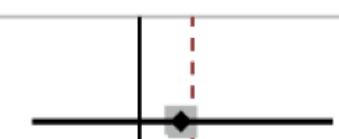

Shiota (2011)

$\mathrm{Bu}(2014)$

Tsolaki (2015)

Overall $(\mathrm{I}-$ squared $=19.1 \%, \mathrm{p}=0.295)$

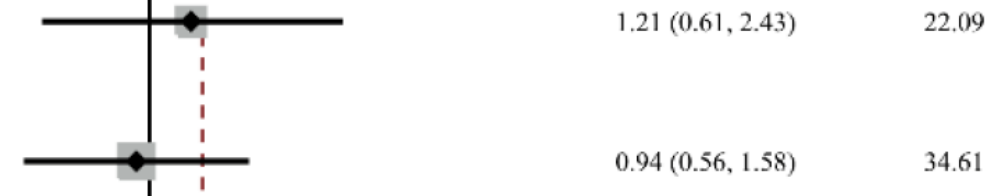

133

(2)

1

$1.39(0.80,2.40) \quad 31.78$

$2.76(1.01,7.51) \quad 11.52$

$1.27(0.89,1.82) \quad 100.00$

Supplementary Figure 5. Re-analysing the association between Helicobacter pylori infection and AD after excluding the study of Kountouras et al. 